Original Article

\title{
The molecular investigations on the subgenus Artemisia Less. of the genus Artemisia L. (Asteraceae) in Turkey
}

\author{
Investigações moleculares sobre o subgênero Artemisia Less. do gênero Artemisia L. \\ (Asteraceae) na Turquia
}

\author{
P. Yilmaz Sancar ${ }^{a^{*}}$ (1), U. Tukur ${ }^{\mathrm{b}}$ (1), S. Civelek ${ }^{\mathrm{a}}$ (1) and M. Kursat ${ }^{\mathrm{c}}$ (1) \\ aFirat University, Faculty of Sciences, Department of Biology, Elazıg, Turkey \\ 'Shehu Shagari College of Education, Department of Biology, Sokoto State, Nigeria \\ 'Bitlis Eren University, Faculty of Arts and Sciences, Department of Biology, Bitlis, Turkey
}

\begin{abstract}
The genus Artemisia L. of the family Asteraceae is systematically very complex. The aim of this study was to evaluate taxonomic positions of taxa of the subgenus Artemisia belonging to the genus Artemisia in Turkey using some molecular techniques. In this molecular study, 44 individuals belong to 14 species of the subgenus Artemisia were examined. Analyses were performed on the combined dataset using maximum parsimony, maximum likelihood and Bayesian inference and Molecular parameters obtained from co-evaluations of sequences of the psbA-trn $\mathrm{H}$, ITS and ETS regions of examined individuals were used in the phylogenetic tree drawing. According to the results of this study, two molecular groups have been formed based on the DNA sequence similarity of the species, but there are no obvious morphological characters corresponding to two molecular groups. There is no also agreement between the two molecular groups and the two morphological groups formed according to the hairiness condition of the receptacle of species. Due to the lack of molecular significance of their receptacles with or without hair, dividing of the subgenus Artemisia species into new subgenera or sections was not considered appropriate. Likewise, it has been found that with or without hair on the corolla lobes of the central hermaphrodite disc flowers have no molecular significance. It was found that there were no gene flow and hybridization between the 14 species of the subgenus Artemisia and these 14 species were found completed their speciation. This study is important as it is the first molecular based study relating with belong to subgenus Artemisia species growing naturally in Turkey. In addition, new haplotypes related to the populations of Turkey belonging to the subgenus Artemisia taxa were reported by us for the first time and added to the GenBank database.
\end{abstract}

Keywords: Artemisia, Turkey, psbA-trnH, ITS, ETS, phylogeny.

\begin{abstract}
Resumo
O gênero Artemisia L. da família Asteraceae é sistematicamente muito complexo. O objetivo deste estudo foi avaliar as posições taxonômicas de táxons do subgênero Artemisia pertencentes ao gênero Artemisia na Turquia usando algumas técnicas moleculares. Neste estudo molecular, 44 indivíduos pertencentes a 14 espécies do subgênero Artemisia foram examinados. As análises foram realizadas no conjunto de dados combinado usando máxima parcimônia, máxima verossimilhança e inferência bayesiana e parâmetros moleculares obtidos a partir de coavaliações de sequências das regiões psbA-trnH, ITS e ETS de indivíduos examinados foram usados no desenho da árvore filogenética. De acordo com os resultados deste estudo, dois grupos moleculares foram formados com base na similaridade da sequência de DNA das espécies, mas não há caracteres morfológicos óbvios correspondentes a dois grupos moleculares. Também não há concordância entre os dois grupos moleculares e os dois grupos morfológicos formados de acordo com a condição de pilosidade do receptáculo da espécie. Devido à falta de significado molecular de seus receptáculos com ou sem cabelo, a divisão das espécies do subgênero Artemisia em novos subgêneros ou seções não foi considerada apropriada. Da mesma forma, verificou-se que com ou sem cabelo nos lobos da corola das flores do disco hermafrodita central não tem significado molecular. Constatou-se que não houve fluxo gênico e hibridização entre as 14 espécies do subgênero Artemisia e essas 14 espécies concluíram sua especiação. Este estudo é importante porque é o primeiro estudo de base molecular relacionado com espécies pertencentes ao subgênero Artemisia crescendo naturalmente na Turquia. Além disso, novos haplótipos relacionados às populações da Turquia pertencentes ao subgênero Artemisia taxa foram relatados por nós pela primeira vez e adicionados ao banco de dados do GenBank.
\end{abstract}

Palavras-chave: Artemisia, Turquia, psbA-trnH, ITS, ETS, filogenia.

*e-mail: peyilmaz@firat.edu.tr

Received: May 28, 2021 - Accepted: July 6, 2021

This is an Open Access article distributed under the terms of the Creative Commons Attribution License, which permits unrestricted use, distribution, and reproduction in any medium, provided the original work is properly cited. 


\section{Introduction}

Artemisia L. is one of the largest genera in the family Asteraceae and the largest genus in the tribe Anthemideae comprises from 200 to more than 500 taxa at the specific or infraspecific level (McArthur, 1979; Mabberley, 1990; Ling, 1991a, b; Bremer and Humpehries, 1993; Ling, 1991a, b; Torrell et al., 1999). Traditionally, the subgeneric classification of the genus Artemisia L. follows a system established by Besser (1829) where in he separated four sections based on various combinations of disc and ray flower occurrences and fertility. These sections are Abrotanum (Duhamel du Monceau) Besser, Absinthium (Miller) Candolle, Dracunculus Besser, and Seriphidium Besser. Besser's four sections have been modified by subsequent workers. Rydberg (1916) created subordinate sections including new section Tridentatae for the North American members of the section Seriphidium and elevated these sections to subgenera.

Nowadays, the most commonly accepted subdivisions of the genus Artemisia are separated into 4 subgenera as Artemisia Lessing, Dracunculus (Besser) Rydberg, Seriphidium Besser ex Lessing and Tridentatae (Rydberg) McArthur et al. (1981). The subgenus Artemisia is included traditional two subgenera Abrotanum Besser and Absinthium (Miller) Lessing. The first detailed phylogenetic interpretation of the sections or subgenera established Artemisia as the more primitive, while Dracunculus, Seriphidium and Tridentatae were considered to be more advanced (Hall and Clements, 1923). Notwithstanding, a major in-depth reclassification of the genus Artemisia (combining molecular and traditional data) has not yet been proposed.

There are 22 species of the genus Artemisia in the $5^{\text {th }}$ volume of the Flora of Turkey (Cullen, 1975; Davis, 1975; Davis et al., 1988). Later, the species A. verlotiorum Lamotte was added to the $10^{\text {th }}$ volume of the Flora of Turkey as a new record for Turkey, so species numbers of the genus Artemisia in Turkey became 23 in total (Kurşat et al., 2011a). At the same time, 23 species without any infraspecific taxa that belong to the genus Artemisa in Flora of Turkey are not classified levels of subgenus or section.

Civelek et al. (2010) have carried out a revisionary study of the genus Artemisia in Turkey. According to the results of this revisionary study, there are a total of 21 species with 9 infraspecific taxa and 3 subgenera belonging to the genus Artemisia in Turkey (Civelek et al., 2010; Kurşat, 2010; Kurşat et al., 2011a, b, 2014, 2015, 2018). According to the results of this revisionary study of the genus Artemisia, subgenera Artemisia, Dracunculus, and Seriphidium have taxa in Turkey, but the subgenus Tridentatae which is endemic to North America has not taxa in Turkey (Civelek et al., 2010; Kurşat, 2010; Guner et al., 2012).

The subgenus Artemisia has the most species in Turkey that includes 14 species. During in the revisionary study, the species A. alba of the subgenus Artemisia Less. has been removed from Turkey's species list because its distribution is outside of Turkey's borders (Civelek et al., 2010; Kurşat, 2010; Kurşat et al., 2011a; Guner et al., 2012). No conclusive consensus has yet been provided on the classification at subgeneric and sectional levels of species belonging to the subgenus Artemisia which is the subject of this study.
During the revisionary study of the genus Artemisia $\mathrm{L}$. in Turkey, the subgenus Artemisia did not divide into new subgenera or sections based on the morphological (phenotypical) character of receptacles which are hairy or glabrous (Civelek et al., 2010; Kurşat, 2010). Is this systematic arrangement of the subgenus Artemisia in this revisionary study that made according to only morphological data correct? The biggest question in the minds of the researchers doing the revisionary study is about whether the dividing at new subgeneric and sectional levels of species belonging to the subgenus Artemisia which is the subject of this study. The final decision on whether the subgenus Artemisia should be divided into new subgenera or sections will be made by this molecular study.

In this study, it will be also tried to determine whether this phenotypic variation has a molecular (genotypic) level response. The purposes of this research are as follows: For the species belonging to the subgenus Artemisia, to determine whether there is a molecular significance of the receptacles with or without hairs and accordingly to determine whether the subgenus Artemisia can be divided into new subgenera or sections. To determine whether the hairy and hairless corolla lobes of the central hermaphrodite disc flowers have a molecular significance for species belonging to the subgenus Artemisia and to find whether each species has completed its speciation. Also, obtain original data on species of subgenus Artemisia for use in new scientific molecular studies of Science World, and to provide the haplotypes of $p s b \mathrm{~A}-t r n \mathrm{H}$, ITS and ETS regions of species belonging to the subgenus Artemisia in Turkey for the GenBank database.

\section{Material and Methods}

\subsection{Plant material}

Within the scope of this study, the plants that were gathered during the land survey conducted by M. Kurşat and S. Civelek were used. 44 individuals belong to 14 species of the subgenus Artemisia were examined. Depending on the large of populations, between 1 and 3 individuals with the same label information were used for each species. Localities and detailed population information the investigated taxa were gathered, were given in Table 1.

\subsection{DNA isolation and PCR amplification}

For the DNA isolation, was used herbarium material (dried plant leaf). The CTAB method was used in a modified form and DNA isolation was performed manually (Doyle and Doyle, 1987). By measuring the concentrations of the isolated DNAs with a nanodrop spectrophotometer, they were adjusted to $25 \mathrm{ng} / \mathrm{ul}$. The Stock DNA was preserved at $-20 \mathrm{C}$.

In the PCR studies conducted by using some spesific universal primers, ITS, ETS and psbA-trn H region for 44 samples was multiplied. The sequence of primers that were used to amplify all of regions were given in Table 2 (Taberlet et al., 1991). Aiming to make the final concentration for the PCR studies to be $50 \mu \mathrm{L}$, by mixing 
Table 1. The label information of examined individuals of specimens belonging to species of the subgenus Artemisia used in the study and detailed localities of populations (Civelek et al., 2010; Kurşat et al., 2011b).

\begin{tabular}{|c|c|c|c|}
\hline $\begin{array}{c}\text { Species of } \\
\text { The Subgenus } \\
\text { Artemisia }\end{array}$ & $\begin{array}{l}\text { Collector and } \\
\text { number of } \\
\text { specimens }\end{array}$ & $\begin{array}{l}\text { Collection } \\
\text { date }\end{array}$ & Detailed localities of specimens' populations \\
\hline A. vulgaris & S.C. and M.K. 1166. & 19.09.2007 & $\begin{array}{l}\text { B9 Bitlis : Between Tatvan and Van,54 km after Tatvan, Besparmak village, stream edge } \\
\text { and roadside, } 1718 \mathrm{~m}, \mathrm{~N} 38^{\circ} 21 \mathrm{E} 42^{\circ} 38\end{array}$ \\
\hline \multirow[t]{3}{*}{ A. verlotiorum } & S.C. and M.K. 1103 & 9.10 .2007 & A6 Ordu : Boztepe, around the recreation facilities of Governor Kemal Yazıcıoğlu, 505 m \\
\hline & S.C. and M.K. 1104 & 29.10.2007 & A7 Giresun : Espiye, Gelevare stream edge, $2 \mathrm{~m}, \mathrm{~N} 40^{\circ} 56 \mathrm{E} 38^{\circ} 43$ \\
\hline & S.C. and M.K. 1105 & 30.10 .2007 & $\begin{array}{l}\text { A8 Rize : Ardeşen - Çamlıhemşin highway, } 2^{\text {nd }} \mathrm{km} \text {, roadside and stream edge, } 9 \mathrm{~m} \text {, } \\
\mathrm{N} 41^{\circ} 10 \mathrm{E} 40^{\circ} 57\end{array}$ \\
\hline \multirow[t]{2}{*}{ A. abrotanum } & S.C. and M.K. 1014 & 01.09.2007 & $\begin{array}{l}\text { B6 Kahramanmaraş: Elbistan -Afşin highway, Ekinözü road junction, Bölek locality, } \\
\text { gardens, } 1147 \mathrm{~m}, \mathrm{~N} 38^{\circ} 11 \mathrm{E} 37^{\circ} 0\end{array}$ \\
\hline & S.C. and M.K. 1044 & 19.09.2007 & B8 Mus: City center entrance, after vocational school, roadside, 1266 m, N 38ํㅜ 47 E $41^{\circ} 29$ \\
\hline \multirow[t]{3}{*}{ A. austriaca } & S.C. and M.K. 1161 & 27.07.2008 & A9 Kars : Kars - Susuz highway, the entrance of Susuz, roadside $1770 \mathrm{~m}, \mathrm{~N} 40^{\circ} 46 \mathrm{E} 43^{\circ} 07$ \\
\hline & S.C. and M.K. 1051 & 20.09.2007 & $\begin{array}{l}\text { B9 Van : Between Çavuştepe castle - Zernek irrigation dam lake, field edges, } 1851 \mathrm{~m} \text {, } \\
\mathrm{N} 38^{\circ} 21 \mathrm{E} 43^{\circ} 33\end{array}$ \\
\hline & S.C. and M.K. 1158 & 26.07.2008 & $\begin{array}{l}\text { B10 Agri : Dogubeyazıt, Igdır highway, between Cengelli pass and Ararat mountain, } \\
\text { Karabulak, Girasor mountain, north slopes of Bardaklı village, steppe, } 2565 \mathrm{~m} \text {, } \\
\text { N } 39^{\circ} 43 \text { E } 44^{\circ} 03\end{array}$ \\
\hline \multirow[t]{3}{*}{ A. incana } & S.C. and M.K. 1075 & 23.09.2007 & $\begin{array}{l}\text { B9 Bitlis : Adilcevaz, Adilcevaz -Ahlat highway, the exit of Adilcevaz, rocky places, } 1720 \\
\text { m, N } 38^{\circ} 47 \text { E } 42^{\circ} 43\end{array}$ \\
\hline & S.C. and M.K. 1079 & 24.09.2007 & $\begin{array}{l}\text { B9 Mus : Malazgirt, between Aktuzla - Karıncalı villages, } 3 \text { km before Karıncalı village, } \\
\text { roadside, rocky places, } 1550 \text { m, N 39ํํㄹ } 212^{\circ} 15\end{array}$ \\
\hline & S.C. and M.K. 1065 & 22.09.2007 & $\begin{array}{l}\text { B10 Agri : Dogubeyazıt, Igdır highway, between Cengelli pass and Ararat mountain, } \\
\text { Karabulak, Girasor mountain, north slopes of Bardaklı village, rocky places, } 1728 \text { m, } \\
\text { N } 39^{\circ} 42 \text { E } 44^{\circ} 05\end{array}$ \\
\hline \multirow[t]{2}{*}{ A. armeniaca } & S.C. and M.K. 1162 & 27.07.2008 & $\begin{array}{l}\text { A9 Kars : Susuz, Kısır Mountain, north slopes of Kiziroğlu Village, meadows, } 2450 \text { m, N } \\
40^{\circ} 54 \text { E } 43^{\circ} 02\end{array}$ \\
\hline & S.C. and M.K. 1144 & 23.09.2007 & $\begin{array}{l}\text { B10 Agri : Dogubeyazıt, Igdır highway, between Cengelli pass and Ararat mountain, } \\
\text { Karabulak, Girasor mountain, north slopes of Bardaklı village, 2565m, N 39ํㅜ } 43 \text { E } 44^{\circ} 03\end{array}$ \\
\hline \multirow[t]{2}{*}{ A. chamaemelifolia } & S.C. and M.K. 1069 & 23.09.2007 & $\begin{array}{l}\text { B10 Agri : Dogubeyazıt, Igdır highway, between Cengelli pass and Ararat mountain, } \\
\text { Karabulak, Girasor mountain, north slopes of Bardaklı village, 2565m, N 39ํ4ㄹ E } 44^{\circ} 03\end{array}$ \\
\hline & S.C. and M.K. 1163 & 27.07.2008 & $\begin{array}{l}\text { A9 Kars : Susuz, Kısır Mountain, north slopes of Kiziroğlu Village, meadows, } 2450 \text { m, } \\
\text { N } 40^{\circ} 54 \text { E } 43^{\circ} 02\end{array}$ \\
\hline \multirow[t]{3}{*}{ A. annua } & S.C. and M.K. 1025 & 08.09.2007 & $\begin{array}{l}\text { A2 (E) Istanbul : North of Terkos lake, wooded area, around the settlement area and } \\
\text { roadside, } 20 \mathrm{~m}\end{array}$ \\
\hline & S.C. and M.K. 1106 & 30.10 .2007 & $\begin{array}{l}\text { A7 Trabzon : Maçka highway, Esiroğlu Kenan Oltan high School, roadside, } 164 \text { m, N } 41^{\circ} \\
10 \text { E } 40^{\circ} 57\end{array}$ \\
\hline & S.C. and M.K. 1024 & 06.09.2007 & B1 Balıkesir : Around Atköy village, 110 m, N 39º 34 E $27^{\circ} 59$ \\
\hline \multirow[t]{2}{*}{ A. tournefortiana } & S.C. and M.K. 1155 & 26.07.2008 & B10 Agrı : Doğubeyazıt, around İshakpaşa palace, ruins, 1953 m, N 39ํㅜ 31 E $44^{\circ} 07$ \\
\hline & S.C. and M.K. 1074 & 23.09.2007 & B9 Bitlis : Adilcevaz, Aydınlar sub-district center, $1891 \mathrm{~m}, \mathrm{~N} 38^{\circ} 53$ E $42^{\circ} 56$ \\
\hline \multirow[t]{3}{*}{ A. absinthium } & S.C. and M.K. 1179 & 27.08.2008 & $\begin{array}{l}\text { B8 Erzurum : Pasinler - Erzurum highway, } 20 \mathrm{~km} \text { before Erzurum, slopes at the side of } \\
\text { the road, } 1915 \mathrm{~m}, \mathrm{~N} 40^{\circ} 38 \mathrm{E} 43^{\circ} 04\end{array}$ \\
\hline & S.C. and M.K. 1080 & 24.09 .2007 & $\begin{array}{l}\text { B9 Mus : Malazgirt, between Aktuzla - Karıncalı villages, } 3 \text { km before Karancılı village, } \\
\text { roadside, rocky places, } 1550 \text { m,N 39ํํㄹ } 21 \text { E } 42^{\circ} 15\end{array}$ \\
\hline & S.C. and M.K. 1063 & 22.09.2007 & $\begin{array}{l}\text { B10 Agrı : Dogubeyazıt, Suluçem, Zor Mountain, north slopes of the water reservoir, } \\
\text { creek, } 2054 \mathrm{~m}, \mathrm{~N} 39^{\circ} 42 \mathrm{E} 43^{\circ} 5\end{array}$ \\
\hline A. arborescens & S.C. and M.K. 1040 & 12.09 .2007 & $\begin{array}{l}\text { C5 Hatay : Samandağı district, Musa mountain, Çevlik location, Titus tunnel area, } 53 \text { m, } \\
\text { N } 36^{\circ} 07 \text { E } 38^{\circ} 55\end{array}$ \\
\hline \multirow[t]{2}{*}{ A. splendens } & S.C. and M.K. 1142 & 21.09.2007 & B9 Van: Gurpinar, Sopakonak village, slopes, 2692 m, N 38ํㅜ 12 E 43ํㅜ 37 \\
\hline & S.C. and M.K. 1072 & 03.09.2007 & $\begin{array}{l}\text { B9 Bitlis: Adilcevaz, Suphan mount, Aydınlar village, upper slopes of Kıçgiller hamlet, } \\
2810 \text { m, N } 38^{\circ} 55 \text { E } 42^{\circ} 52\end{array}$ \\
\hline \multirow[t]{2}{*}{ A. alpina } & S.C. and M.K. 1149 & 13.07.2008 & $\begin{array}{l}\text { B6 Sivas: Ulaş district, Tecer mount, lower parts of the oak community, around the water } \\
\text { resources, rocky places, } 1817 \mathrm{~m}, \mathrm{~N} 39^{\circ} 25 \mathrm{E} 37^{\circ} 07^{\circ}\end{array}$ \\
\hline & S.C. and M.K. 1006 & 06.07 .2007 & $\begin{array}{l}\text { C5 Niğde: Çamardı district, lower parts of Demirkazık village, steppe areas, } 1560 \mathrm{~m} \text {, } \\
\text { N } 37^{\circ} 51 \text { E } 35^{\circ} 04\end{array}$ \\
\hline A. haussknechtii & S.C. and M.K. 1059 & 21.09.2007 & $\begin{array}{l}\text { C9 Hakkari : Hakkari - Van highway, after } 20^{\text {th }} \mathrm{km} \text {, Kırıkdağ village, Kırbaş castle, the } \\
\text { upper part of Ovaspi stream, rock places, } 1624 \mathrm{~m} \text {, N } 37^{\circ} 34 \mathrm{E} 43^{\circ} 5\end{array}$ \\
\hline
\end{tabular}


$10 \mu \mathrm{L}$ buffer, $3 \mu \mathrm{L} \mathrm{MgCl} 2,1 \mu \mathrm{L}$ dNTPs, $0.50 \mu \mathrm{L}$ from each primer (forward and reverse), $0.50 \mu \mathrm{L}$ taq polymerase, 32.30 $\mathrm{dH}_{2} \mathrm{O}$, and nearly $12 \mathrm{ng}(2.70 \mu \mathrm{L})$ template of DNA were mixed and the PCR device was repeated for 30 cycles, having $2 \min 94^{\circ} \mathrm{C}$ initial denaturation, $1 \mathrm{~min} 94^{\circ} \mathrm{C}$ denaturation, $35 \mathrm{~s} 50{ }^{\circ} \mathrm{C}$ (for psbA - trn H region), and $55^{\circ} \mathrm{C}$ (for ITS and ETS region) annealing, $2 \mathrm{~min} 72{ }^{\circ} \mathrm{C}$ extension and $10 \mathrm{~min}$ $72{ }^{\circ} \mathrm{C}$ final extension. PCR products were monitored in agarose gel with a $2 \%$ ratio.

\subsection{Sequence and phylogenetic analysis}

A two-way reading was applied to the amplification products. The PCR purification process was realized before the sequence analysis. The purification and sequencing process was realized by the Macrogen Company. In order to evaluate the data of the chromatograms, a Finch TV 1.4 version was used. The variable sites, number of parsimony informative sites, genetic distance, nucleotide diversity, and divergence within the species were computed as molecular diversity statistics for each dataset using Molecular Evolutionary Genetics Analysis software (MEGA X) (Kumar et al., 2018). The DNA sequence alignments of

Table 2. The base sequences of the primers used (Taberlet et al., 1991).

\begin{tabular}{cc}
\hline Primers & Base sequences (5' - 3’) \\
\hline ITS5 & 5' GAA AGT AAA AGT CGT AAC AAG G 3' \\
ITS4 & 5' TCC TCC GCT TAT TGA TAT GC 3' \\
ETS1f & 5' CTT TTT GTG CAT AAT GTA TAT ATA GGG GG 3' \\
18S-2L & 5' TGA CTA CTG GCA GGA TCA ACC AG 3' \\
psbA & 5' GTT ATG CAT GAA CGT AAT GCT C 3' \\
$t r n H$ & 5' CGC GCA TGG TGG ATT CAC AAT CC 3' \\
\hline
\end{tabular}

the 44 individuals were evaluated by using the $\mathrm{X}$ version of the MEGA program. The DNA sequence alignments of all the individuals was subject to the statistical analysis within the scope of this program. Ultimately, the phylogenetic trees were constructed by using the Maximum Likelihood Method with 100 bootstrap replicates. The GenBank accession numbers, where the investigated taxa were gathered, are given in Table 3.

\section{Results}

In this research, 44 individuals belong to 14 species of the subgenus Artemisia were examined. Depending on the numbers of individuals in the herbarium specimens, between 1 and 3 individuals with the same label information were used for each specimen. The sequences of the cpDNA psbA-trnH, r-DNA ITS and ETS regions for all individuals examined, were used to determine phylogenetic kinship relationships.

The peak results of the bi-directional sequences sent from the Macrogen were evaluated using Version 1.4 of the Finch TV program. Using the "Multiple Alignment Blast System" of the automatic sequencing systems, sequences were aligned. The differences in the noticeable were manually corrected.

As a result of scans performed in the NCBI (National Center for Biotechnology Information) database site, for seven species of the subgenus Artemisia, three reference regions were obtained. These reference regions were an ITS with 700-750 bases (ITS1-5.8 gene - ITS2), ETS with 400-450 bases and psbA-trn H with $450-500$ bases. For a more accurate visualization of the results of the alignment, about 50-100 base from the head and the end was not evaluated by us. For this reason, approximately 684 base pairs for the ITS regions, 506 base pairs for the ETS regions

Table 3. GenBank accession numbers for the r-DNA ITS, ETS and psbA-trnH regions of the studied samples.

\begin{tabular}{|c|c|c|c|}
\hline \multirow{2}{*}{$\begin{array}{c}\text { Taxa of the Subgenus } \\
\text { Artemisia }\end{array}$} & \multicolumn{3}{|c|}{ GenBank Accesion Numbers } \\
\hline & ITS region & psbA-trnH region & ETS region \\
\hline A. vulgaris $1-3$ & MT734913- MT734915 & MT758494- MT758496 & MT758538- MT758540 \\
\hline A. verloitorum 1-4 & MT734916- MT734919 & MT758497- MT758500 & MT758541- MT758544 \\
\hline A. abrotanum 1-3 & MT734920- MT734922 & MT758501- MT758503 & MT758545- MT758547 \\
\hline A. austriaca 1-3 & MT734923- MT734925 & MT758504- MT758506 & MT758548- MT758550 \\
\hline A. incana 1-3 & MT734926- MT734928 & MT758507- MT758509 & MT758551- MT758553 \\
\hline A. armeniaca 1-2 & MT734929- MT734930 & MT758510- MT758511 & MT758554- MT758555 \\
\hline A. chamaemelifolia 1-4 & MT734931- MT734934 & MT758512- MT758515 & MT758556- MT758559 \\
\hline A. annua 1-3 & MT734935- МT734937 & MT758516- MT758518 & MT758560- MT758562 \\
\hline A. tournefortiana 1-3 & MT734938- MT734940 & MT758519- MT758521 & MT758563- MT758565 \\
\hline A. absinthinium 1-3 & MT734941- MT734943 & MT758522- MT758524 & MT758566- MT758568 \\
\hline A. arborescens 1-2 & MT734944- MT734945 & MT758525- MT758526 & MT758569- MT758570 \\
\hline A. splendens $1-4$ & MT734946- МT734949 & MT758527- MT758530 & MT758571- MT758574 \\
\hline A. alpina $1-4$ & MT734950- MT734953 & MT758531- MT758534 & MT758575- MT758578 \\
\hline A. haussknechtii 1-3 & MT734954- MT734956 & MT758535- MT758537 & MT758579- MT758581 \\
\hline
\end{tabular}


and 466 base pairs for the psbA - trnH regions were used and the Genbank accesion number of these regions were given in the Table 3.

The DNA sequences of the ITS, ETS and the psbA-trnH regions of 44 individuals belong to subgenus Artemisia were analyzed statistically. In the both separate and co-evaluations of sequences of the ITS, ETS and psbA-trnH regions of examined individuals, some parameters of molecular diversity like conservated regions (C), variation regions $(\mathrm{V})$, parsimony informative regions $(\mathrm{Pi})$, single parts (S), homologous base pairs (ii), transitional base pairs (si), transversional base pairs (sv) and R value (si / sv) were calculated and the values obtained are given in Table 4 . These parameters determine the distribution of individuals in the phylogenetic tree and thus gave us information about their phylogenetic relationships.

The nucleotide composition of the individuals was determined as a result of the statistical analyzes performed by cutting the excess parts at the head and end of the DNA sequences. When the values given in Table 4 are examined, it is seen that individuals are not very different in terms of the ratio of T, C, A, and G bases. At the same time, it was found that when the average values of the base contents of the individuals were calculated, the A-T ratio was 56\% and the $\mathrm{G}-\mathrm{C}$ ratio was $44 \%$, and the A-T base pair was richer than $\mathrm{G}-\mathrm{C}$ base pair.

In order to determine the phylogenetic relationships between individuals belonging to subgenus Artemisia species from both the same and different populations, in total 52 individuals were studied, 7 of them were control group and 1 of which was outgroup were arranged in Mega program.

Then, by using the Best DNA / Protein step in the Models menu of this program, we determined the methods that best express the phylogenetic relationship between individuals. In the list of methods given, the lowest value of BIC (Bayesian Information Criterion) was found in the $\mathrm{T} 92+\mathrm{G}$ (Tamura-3-parameter) method. According to T92 + G, to see phylogenetic relationships between individuals, we have seen that phylogenetic trees can be plotted using any of the methods such as Maximum Parsimony, NeighborJoining, UPGMA, and Maximum Likelihood.

Maximum Likelihood, Neighbor-Joining, UPGMA, and Maximum Parsimony methods were applied separately, but it was decided that the method that best illustrates the evolutionary and phylogenetic relations among the examined individuals, we work with is the Maximum Likelihood method. In the phylogenetic tree drawing, the DNA sequences of ITS and ETS regions in the nuclear genome and $p s b \mathrm{~A}-t r n \mathrm{H}$ in the chloroplast genome were co-evaluated by using version 7.1 of the Mega program. In the Maximum Likelihood method, by entering the boostrap value 100 , a single phylogenetic tree for a total of 52 individuals were obtained (Figure 1 ).

\section{Discussions}

There are 3 subgenera, 24 species with 5 infraspecific taxa belong to the genus Artemisia in Turkey. The subgenus Artemisia includes 14 species, the subgenus Dracunculus includes 4 species and the subgenus Seriphidium includes 6 species with 5 taxa that settled in the categories of subspecies and variety. Three species (A. santonicum, A. taurica, and $A$. sieberi) of the subgenus Seriphidum have five infraspecific taxa that settled in the categories of subspecies and variety (Table 5) (Civelek et al., 2010; Kurşat, 2010; Kurşat et al., 2011a, b, 2014, 2015, 2018). Although the subgenus Artemisia has been divided into new second subgenera or sections by some authors (Bremer and Humpehries, 1993; Schinskin and Bobrov, 1995; Ling et al., 2006; Shultz, 2006a, b), the subgenus Artemisia did not divide to new subgenera or sections during the revisionary study of the genus Artemisia in Turkey (Civelek et al., 2010; Kurşat, 2010). The most importanat of the purposes of this molecular study is to make the final decision whether the subgenus Artemisia should be divided into new subgenera or sections.

Table 4. Molecular diversity parameters obtained from both separate and co-evaluations of sequences of the ITS, ETS and psbA-trnH regions of examined individuals.

\begin{tabular}{ccccc}
\hline $\begin{array}{c}\text { Parameters of Molecular } \\
\text { Diversity }\end{array}$ & ITS region & ETS region & psbA-trnH region & $\begin{array}{c}\text { Co-evaluated of ITS, } \\
\text { ETS and psbA-trnH }\end{array}$ \\
\hline Total individuals & 44 & 44 & 44 & 44 \\
Total band Length & $\sim 684$ & $\sim 504$ & $\sim 466$ & $\sim 1716$ \\
The ratio of G-C base pair (\%) & 54.1 & 49.6 & 29.5 & 44 \\
Conserved regions (C) & 410 & 429 & 392 & 763 \\
Variation regions (V) & 285 & 75 & 45 & 917 \\
Single parts (S) & 85 & 1 & 41 & 141 \\
Parsimony informative regions (Pi) & 200 & 74 & 450 & 776 \\
Homologous base pairs (ii) & 633 & 483 & 3 & 1305 \\
Transitional base pairs (si) & 27 & 14 & 5 & 117 \\
Transversional base pairs (sv) & 15 & 6 & 0.5 & 201 \\
R value (si/sv) & 1.8 & 2.3 & & 0.6 \\
\hline
\end{tabular}




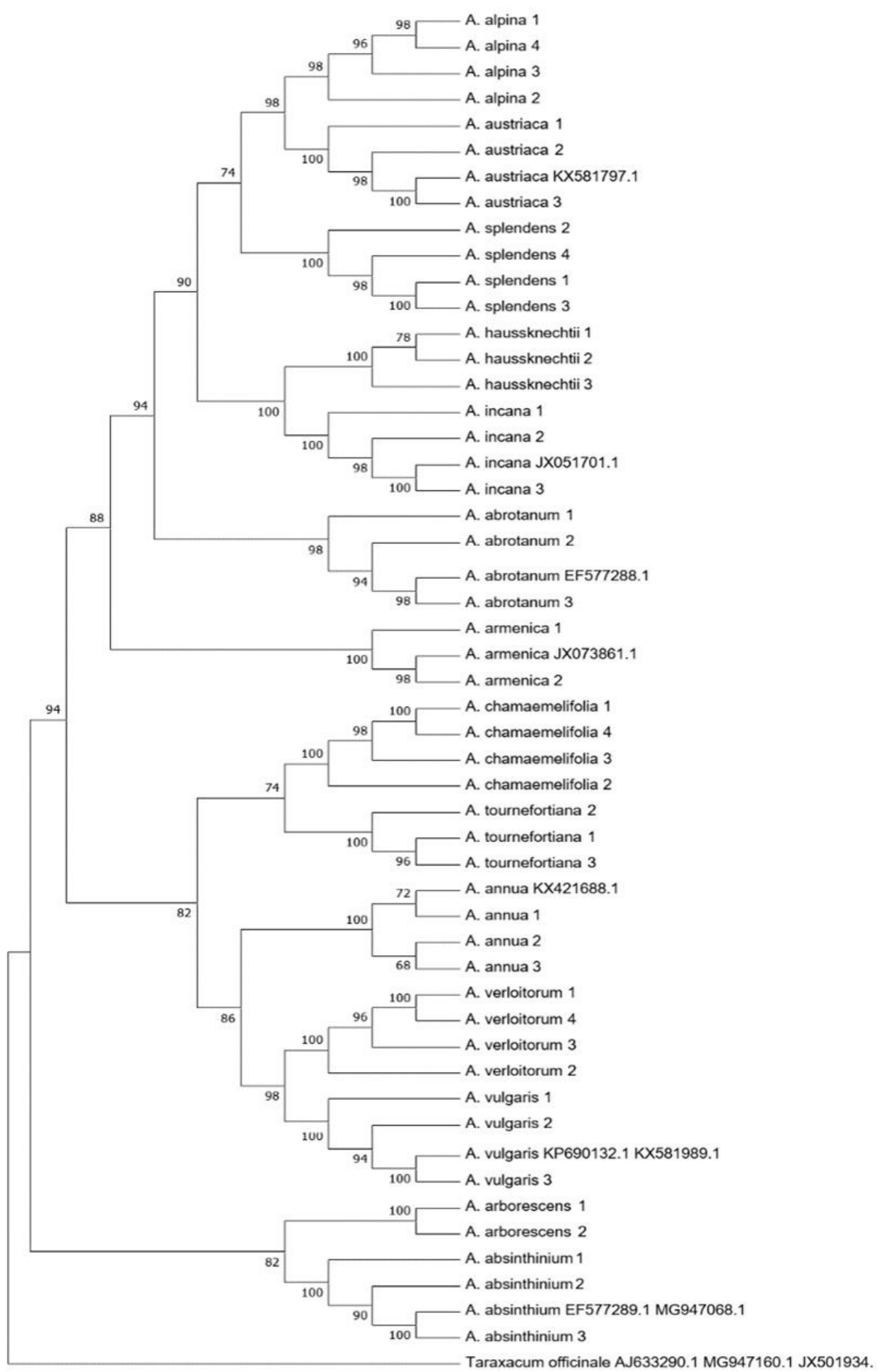

Figure 1. Phylogenetic tree obtained from the co-evaluation of sequences of the psbA-trnH, ETS and ITS regions of individuals.

During the revisionary study of the genus, Artemisia in Turkey, a new diagnostic character (a new phenotypic variation) had been determined for taxa belonging to subgenus Artemisia. This diagnostic character is that with or without hair on the corolla lobes of the central hermaphrodite disc flowers. Four species A. arborescens,
A. armeniaca, A. austriaca, and A. incana of the subgenus Artemisia have hairs on the corolla lobes of central hermaphrodite disc florets. However, ten species A. vulgaris, A. verloitorum, A. abrotanum, A. chamaemelifolia, A. annua, A. tournefortiana, A. absinthium, A. splendens, A. alpina and A. haussknechtii of the subgenus Artemisia have not hairs 
on the corolla lobes of central hermaphrodite disc florets. Different researchers have taxonomically classified of the subgenus Artemisia at subgeneric and sectional levels according to whether receptacle has hairy or glabrous (Table 5).

After the revisionary study, new research projects have been carried out for problematic taxa of the two subgenera Seriphidium and Drancunculus of the genus Artemisia in Turkey (Civelek and Sancar, 2012; Civelek et al., $2018,2019)$. Taking into account the results of these new research projects, some new arrangements have been made for taxa of the genus Artemisia in Turkey. The species A. fragrans Willd. is published as a new record for Turkey. A. taurica var. vanensis Kursat \& Civelek is published as a new variety globally (Kurşat et al., 2014, 2018). A. campestris var. campestris, A.campestris var. marschalliana and A.campestris var. araratica that are new combinations in the revisionary study was proposed to raise to species level again (Civelek et al., 2019). Thus, like in the Flora of Turkey, the new systematic positions and combinations of the three varieties of the species $A$. campestris became independent species $A$. campestris, $A$. marschalliana, and A. araratica, like the Flora of Turkey (Table 6) (Civelek et al., 2019; Sancar et al., 2022).

In the scope of this molecular study, 44 individuals belong to 14 species of the subgenus Artemisia were examined. For all examined individuals, belonging to species of the subgenus Artemisia, the sequences of regions with cpDNA psbA-trnH region, r-DNA ITS and ETS region, have been used to determine the phylogenetic relationship between 44 individual.

If we carefully look the phylogenetic tree in Figure 1, the species are divided into two primary branches. In the first primary branch, it is seen that the species $A$. arborescens and $A$. absinthium differentiate with $82 \%$ strong boostrap value from all other species of the subgenus.

The second primary branch carries the remaining 12 species with a strong boostrap value of $94 \%$. The second primary branch is also divided into two secondary level branches. One of these secondary level branches carries the species A. chamaemelifolia, A. tournefortiana, A. annua, A. vulgaris, A. verlotiorum, while the other secondary level branch carries the species A. abrotanum, A. austriaca, A. incana, A. armeniaca, A. splendens, A. alpina, A. haussknechtii (Table 7).

The first primary branch carries two species whose receptacles are only hairy, while other primary branch carries the species whose receptacles are both hairy and hairless. One of the secondary level two branches of other primary branch carries five species whose receptacles are only hairless, other secondary level branch carries seven species whose receptacles are both hairy (three species) and hairless (four species). This molecular grouping may be related to the polyphyletic origin of the subgenus Artemisia. It is stated in the literature that the subgenus Artemisia is polyphyletic while the other subgenera are monophyletic (Hussain et al., 2019). Also, this subgenus must to be recircumscribed stated, indicated by Hussain et al. (2019).

There is no agreement between two molecular groups in the phylogenetic tree created on the basis of the DNA sequence similarity of the species and the two morphological groups formed according to the hairiness condition of the receptacles. In this study, as it was determined that lack of molecular significance of their receptacles with or without hair, dividing of the subgenus Artemisia species into new subgenera or sections was not considered appropriate. As known, even during the revisionary study of the genus Artemisia in Turkey which

Table 5. Different taxonomic classifications of the subgenus Artemisia at subgeneric and sectional levels according to receptacle with or without hair (Kursat 2010).

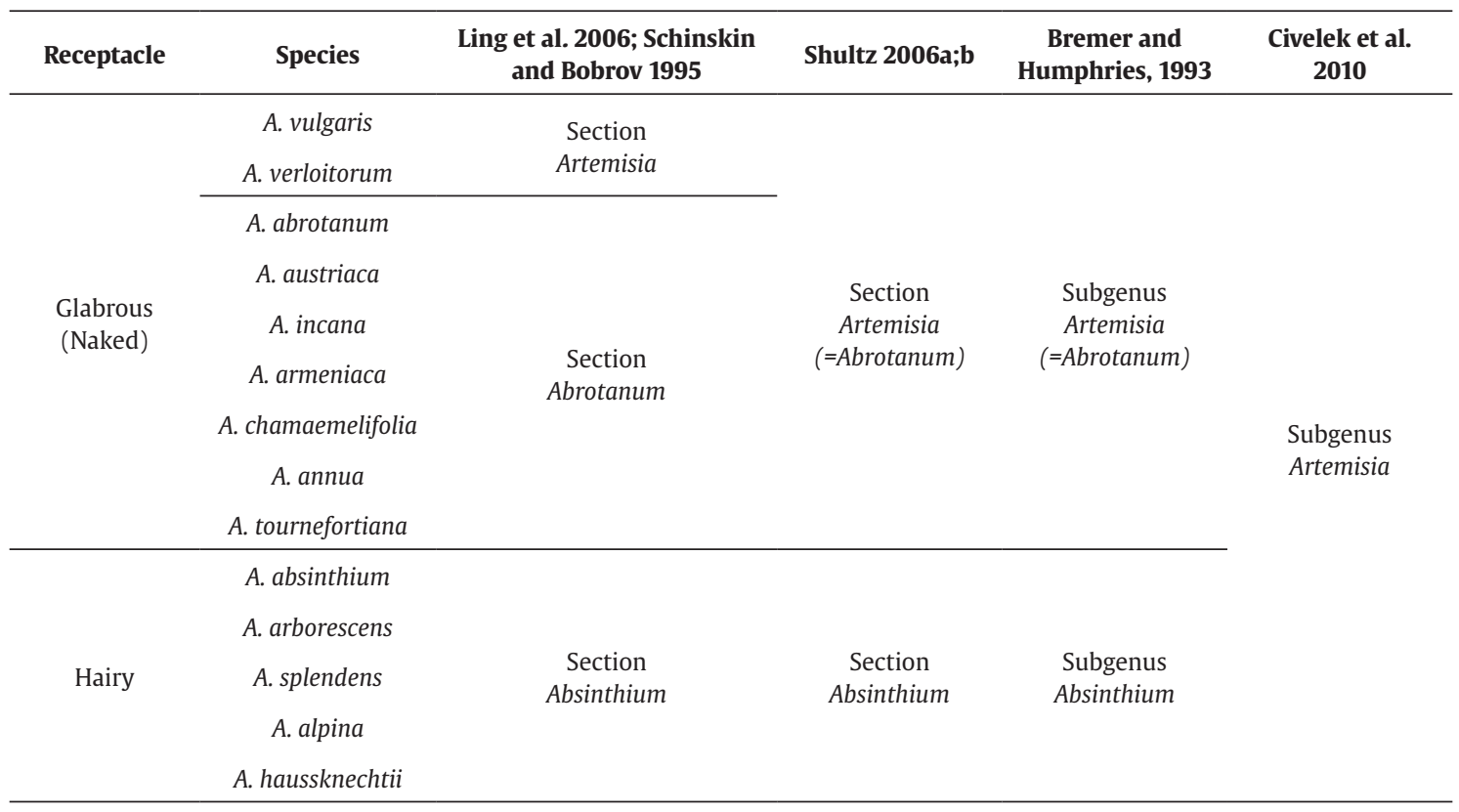


Table 6. The final status of the all taxa of the genus Artemisia in Turkey.

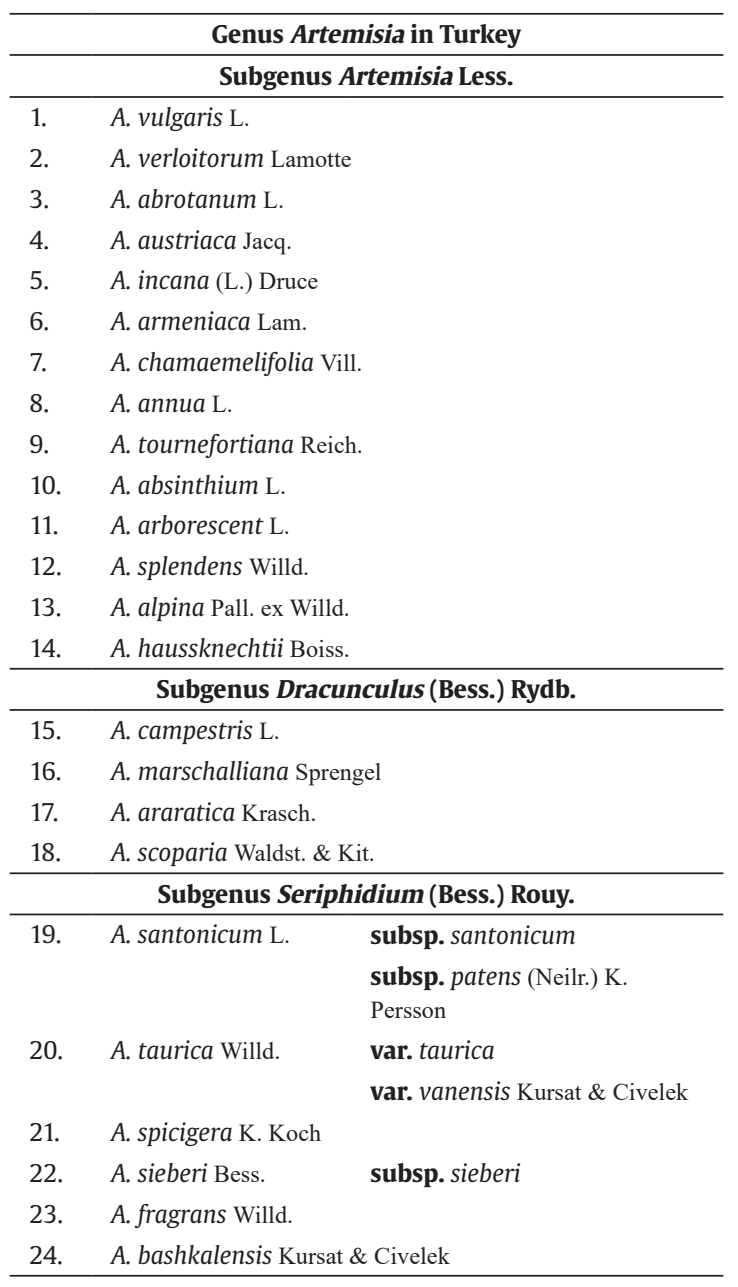

based on morphological characters, the subgenus Artemisia did not divide into subgenera and sections (Civelek et al., 2010; Kurşat, 2010). The correctness of this classification was determined by the current molecular study. Although the receptacle with or without hair can be appropriately not used for classification in molecular systematics of the subgenus Artemisia, it is known that it is extremely useful in the morphological identification of species.

Likewise, it has been found that with or without hair on the corolla lobes of the central hermaphrodite disc flowers have no molecular significance. Four species (A. austriaca, A. incana, A. armeniaca, A. arborescens) that have hairs on the corolla lobes of central hermaphrodite disc florets distributed into two molecular groups in half. A. arborescens is one of the two species found in the first primary branch. A. austriaca, $A$. incana and A. armeniaca species are three of the seven species in the second branch of the other primary branch. The secondary branch of the other primary branch with five species hasn't any species with hair on the corolla lobes of the central hermaphrodite disc flowers.

It is also an important finding that individuals of fourteen species belonging to the subgenus Artemisia are located only on the same branches of the phylogenetic tree with their species individuals and own control group members, and not to interfere with individuals belonging to other species. This situation is also a molecular indication that there is reproductive isolation among fourteen species and there is no gene flow and hybridization between them. Although some of the species of the subgenus Artemisia morphologically similar to each other in outline, the samples of each species belonging to the subgenus Artemisia are easily distinguishable from the samples of another species of this subgenus and there is no difficulty in their identification. In other words, even if only considering their morphological characters, it seems that the species belonging to the subgenus Artemisia have completed their

Table 7. The hairiness of both receptacle and corolla lobes in the species of subgenus Artemisia, molecular groups formed as a result of phylogenetic analysis

\begin{tabular}{cccc}
\hline Species & Receptacle & $\begin{array}{c}\text { Corolla Lobes of Central } \\
\text { Hermaphrodite Disc Florets }\end{array}$ & Molecular Group \\
A. alpina & Hairy & Glabrous & \\
A. splendens & Glabrous & Hairy & Glabrous \\
A. haussknechtii & Hairy & Glabrous & II. Secondary Group \\
A. incana & Glabrous & Hairy & \\
A. abrotanum & Glabrous & Glabrous & I. Primary Group \\
A. armeniaca & Glabrous & Hairy & \\
\hline A. chamaemelifolia & Glabrous & Glabrous & I. Secondary Group \\
A. tournefortiana & Glabrous & Glabrous & \\
A. annua & Glabrous & Glabrous & \\
A. verloitorum & Glabrous & Glabrous & I. Primary Group \\
A. vulgaris & Glabrous & Glabrous & \\
\hline A. arborescens & Hairy & Hairy & \\
A. absinthium & Hairy & Glabrous & \\
\hline
\end{tabular}


speciation and there is no hybridization between them (Civelek et al., 2010; Kurşat, 2010). These molecular study data confirmed this generalization obtained only from morphological data.

The fact that the individuals of the seven species used as the control group are only in the same branches with individuals belonging to their own species makes our study $100 \%$ reliable.

As a result of this research, it was obtained original data for use in new scientific molecular studies on the taxa of genus Artemisia and provided the haplotypes of ETS, ITS and psbA-trnH regions for 14 species of the subgenus Artemisia in Turkey for the GenBank database (Table 3).

This study reports for the first time, molecular phylogeny of subgenus Artemisia from Turkey by using r-DNA (ITS and ETS) and cpDNA (psbA-trnH) sequences.

Based on the current data and all available in literature, it is concluded that the morphological studies coupled with modern molecular techniques may lead to the clear infrageneric classification of the genus Artemisia.

\section{Acknowledgements}

This work was supported by the Firat University Scientific Research Projects Coordination Unit [grant number: FF.19.21].

\section{References}

BESSER, W., 1829. Synopsis Absinthium. Bulletin de la Société Impériale des Naturalistes de Moscou, vol. 1, pp. 219-265.

BREMER, K. and HUMPEHRIES, C.J., 1993. Generic monograph of the Asteraceae-Anthemideae. Bulletin of the British Museum (Natural History). Botany, vol. 23, no. 2, pp. 71-177.

CIVELEK, S. and SANCAR, P.Y. 2012. The morphological and Karyological Investigation of Artemisia Spicigera C.Koch Populations that Around Van Lake. Turkey: Firat University. Research project FUBAP - 2090.

CIVELEK, S., SANCAR, P.Y. and DELIPOYRAZ, S., 2018. The investigation by using some molecular markers on the phylogenetic relationships of the populations of Artemisia taurica Willd. (Asteraceae) in Turkey. Turkey: Firat University. Research project FUBAP- FF.16.17.

CIVELEK, S., SANCAR, P.Y. and WAHID, C.F., 2019. The investigation on the chloroplast and nuclear genomes of taxa belong to the subgenus Dracunculus (Bess.) Rydb. of Artemisia L. (Asteraceae) in Turkey. Turkey: Firat University. Research project FUBAP -FF.17.28.

CIVELEK, S., YILMAZ, O., BAGCI, E., KIRBAG, S., GUR, N., TURKOGLU, I., TABUR, S. and KURSAT, M., 2010. The researches of taxonomical, hemical (Flavonoids and Essential oils), karyological, palynological and antimicrobial activities on taxa of the genus Artemisia L. (Asteraceae) growing in Turkey. Turkey. TUBITAK TBAG-106T559.

CULLEN, J., 1975. Artemisia L. In: P.H. DAVIS, ed. Flora of Turkey and the East Aegean Islands. Edinburgh: Edinburgh University Press, vol. 5, pp. 311-324.

DAVIS, P.H., ed., 1975. Flora of Turkey and the East Aegean Islands. Edinburgh: Edinburgh University Press, vol. 5, pp. 311-324.

DAVIS, P.H., MILL, R.R. and TAN, K., 1988. Flora of Turkey and the East Aegean Islands. Edinburgh: Edinburgh University Press, vol. 10, pp. 163-164.
DOYLE, J.J. and DOYLE, J.L., 1987. A rapid DNA isolation procedure for small quantities of fresh leaf tissue. Phytochemical Bulletin, vol. 19, pp. 11-15.

GUNER, A., ASLAN, S., EKIM, T., VURAL, M. and BABAC, M.T., 2012. Turkiye Damarli Bitkiler Listesi. Turkey: Nezahat Gökyigit Botanik Bahcesi ve Flora Araştirmalari Dernegi Yayini, pp. 118-120.

HALL, H.M. and CLEMENTS, F.E., 1923. The phylogenetic method in taxonomy. The North American species of Artemisia, Chrysothamnus and Atriplex. Carnegie Institution of Washington, vol. 326, pp. 355. http://dx.doi.org/10.5962/bhl.title.13922.

HUSSAIN, A., POTTER, D., KIM, S., HAYAT, M.Q. and BOKHARI, S.A.I., 2019. Molecular phylogeny of Artemisia (AsteraceaeAnthemideae) with emphasis on undescribed taxa from GilgitBaltistan (Pakistan) based on nrDNA (ITS and ETS) and cpDNA (psbA-trnH) sequences. Plant Ecology and Evolution, vol. 152, no. 3, pp. 507-520. http://dx.doi.org/10.5091/plecevo.2019.1583.

KUMAR, S., STECHER, G., LI, M., KNYAZ, C. and TAMURA, K., 2018. MEGA X: molecular evolutionary genetics analysis across computing platforms. Molecular Biology and Evolution, vol. 35, no. 6, pp. 1547-1549. http://dx.doi.org/10.1093/molbev/ msy096. PMid:29722887.

KURŞAT, M., 2010. The taxonomic revision of the genus Artemisia L. (Asteraceae) growing in Turkey. Elazığ: Institute of Science and Technology, Firat University Biology Department. PhD thesis in Botany.

KURŞAT, M., CIVELEK, S., TURKOGLU, I. and TABUR, S., 2011a. Artemisia sieberi Besser subsp. sieberi a new record for Turkey and a delete record for Turkey Artemisia herba-alba Asso. (Asteraceae). Pakistan Journal of Botany, vol. 43, no. 4, pp. 1819-1821.

KURŞAT, M., TURKOGLU, I., CIVELEK, S. and TABUR, S., 2011b. A new subspecies records for the flora of Turkey: Artemisia santonicum L. subsp. patens (Neilr.) K.M. Perss. (Asteraceae). Turkish Journal of Botany, vol. 35, no. 1, pp. 89.

KURŞAT, M., SANCAR, P.Y. and CIVELEK, S., 2014. New record for the flora of Turkey, Artemisia fragrans Willd. (Asteraceae). The Herb Journal of Systematic Botany, vol. 21, no. 2, pp. 49-58.

KURŞAT, M., CIVELEK, S., TURKOGLU, I., TABUR, S. and GUR, N., 2015. A new species of the subgenus Seriphidium of the genus Artemisia L. (Asteraceae) from Turkey. Turkish Journal of Botany, vol. 39, pp. 88-95. http://dx.doi.org/10.3906/bot-1311-33.

KURŞAT, M., CIVELEK, S., SANCAR, Y.P. and TURKOGLU, I., 2018. Artemisia taurica Willd. var. vanensis Kursat \& Civelek (Asteraceae: Anthemideae), a new variety from Eastern Anatolia of Turkey. Biological Diversity and Conservation, vol. 11, no. 3, pp. 106-114.

LING, Y.R., 1991a. The Old World Seriphidium (Compositae). Bulletin of Botanical Research, vol. 11, no. 4, pp. 1-40.

LING, Y.R., 1991b. The Old World Artemisia (Compositae). Bulletin of Botanical Research, vol. 12, no. 1, pp. 1-108.

LING, Y.R., HUMPHRIES, C.J. and SHULTZ, L., 2006. The genus Artemisia L. In: FLORA OF CHINA EDITORIAL COMMITTEE, ed. Flora of China. Beijing: Science Press, vol. 20, pp. 1151-1259.

MABBERLEY, D., 1990. The plant-book. 2nd ed. Cambridge: Cambridge University Press.

MCARTHUR, E.D., 1979. Sagebrush systematics and evolution. In: UTAH STATE UNIVERSITY, ed. Sagebrush Ecosystem Symposium. Logan: Utah State University, pp. 14-22.

MCARTHUR, E.D., POPE, C.L. and FREEMAN, D.C., 1981. Chromosomal Studies of subgenus Tridentatae of Artemisia, Evidence for Auto polyploidy. American Journal of Botany, vol. 68, no. 5, pp. 589-605. http://dx.doi.org/10.1002/j.1537-2197.1981.tb12391.x. 
RYDBERG, P.A., 1916. Artemisia and Artemisiastrum. North American Flora, vol. 34, no. 3, pp. 244-285.

SANCAR, P.Y., WAHI D, C.F., CIVELEK, S. and KURSAT, M., 2022. An investigation on the chloroplast and nuclear genomes of taxa belong to the subgenus Dracunculus (Bess.) Rydb. of Artemisia L. (Asteraceae) in Turkey. Brazilian Journal of Biology $=$ Revista Brasileira de Biologia, vol. 82, pp. e242403. http://dx.doi. org/10.1590/1519-6984.242403.

SCHINSKIN, B.K. and BOBROV, E.G., 1995. Genus 1550 Artemisia. In: B.K. ŠIŠKIN, ed. Flora of The USSR. Dehra Dun: Bishen Singh Mahendra Pal Singh, vol. 27, pp. 404-600.

SHULTZ, L.M., 2006a. Subgeneric concepts in Artemisia L. (Asteraceae: Anthemideae): the Tridentatae revisited. In: Y.R. LING, ed.
International Symposium on the genus Artemisia and allies. Beijing: South China Institute of Botany, pp. 36-44.

SHULTZ, L.M., 2006b. Artemisia. In: FLORA OF NORTH AMERICA EDITORIAL COMMITTEE, ed. Flora of North America north of Mexico. New York: Oxford University Press, vol. 21, pp. 503-534.

TABERLET, P., GIELLY, L., PAUTOU, G. and BOUVET, J., 1991. Universal primers amplification of three non-coding regions of chloroplast DNA. Plant Molecular Biology, vol. 17, no. 5, pp. 1105-1109. http:// dx.doi.org/10.1007/BF00037152. PMid:1932684.

TORRELL, M., GARCIA-JACAS, N., SUSANNA, A. and VALLÊS, J., 1999. Phylogeny in Artemisia (Asteraceae, Anthemideae) inferred from nuclear ribosomal DNA (ITS) sequences. Taxon, vol. 48, no. 4, pp. 721-736. http://dx.doi.org/10.2307/1223643. 